<綜 説 $>$

（受理 : 平成 15 年 10 月 15 日）

\title{
ガス用ポリエチレン管の融着部の信頼性 Reliability of Fusion Joints of Polyethylene Pipes for Gas Distribution
}

\section{1.はじめに}

ガス用ポリエチレン管は, 軽量で可とう性を有し腐食

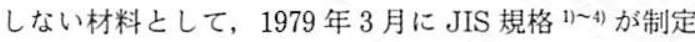
されまた 1982 年 11 月にガス事業法の技術基準に低圧 ガス導管の材料として新たに制定された後，ガス事業者 に正式に導入された。その後 1995 年 1 月の阪神・淡路 大震災を契機に全国のガス会社にて全面的に普及促進が 図られた。図1に全国のポリエチレン管の使用実績を示 す。1995 年の阪神・淡路大震災を契機に使用量が急増 し，現在年間約 1 万 $1500 \mathrm{~km}$ の管が安定して使用されて いる。ガス用ポリエチレン管を用いたガス配管システム には，管と管の接合部と管と継手の接合部を含んでいる

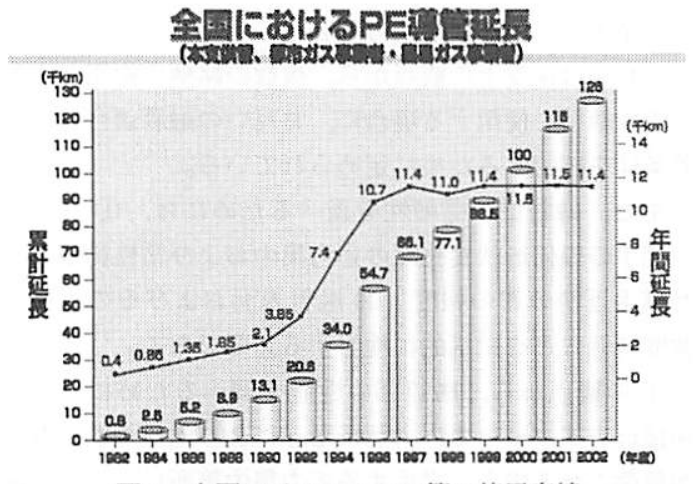

図 1 全国のポリエチレン管の使用実績

*大阪ガス(林)エネギー技術研究所

大阪市此花区西岛 6丁目 19-9 テ 554-0051

Energy Technology Laboratories

OSAKA GAS CO., LTD.

6-19-9, Torishima Konohana-ku, OSAKA 554-0051, Japan
西村寛之* Hiroyuki NISHIMURA

ので，管母材だけでなく接合部の信頼性を確保すること が重要である。ポリエチレン管の接合には, 接合面を互 いに溶融し, 圧着する方法 (融着) が取られるので, 一 般的に接合が容易で信頼性が高いと言われている。

\section{2. ポリエチレン管の接合方法}

ガス用ポリエチレン管には熱融着法にて管と管または 管と継手を接合する方式が採用されてきた。熱融着のた めの継手は一般的にヒートフュージョン (HF) 継手と 呼ばれている。また, 近年継手の内面に埋め込まれた電 熱線（ワイヤー）の発熱によって融着するエレクトロフュー ジョン（EF）継手いわゆる電気融着継手が普及してき ている。熱融着法による管と管の接合にはバット融着に よる突合せ接合が用いられ，管と継手の接合にはソケッ ト形接合と，管と側面より分岐管を取り出すためにサト ル形接合が用いられている。口径が $50 \mathrm{~mm}$ 以上の管と 管との接合にはバット融着が効果的であるが, $50 \mathrm{~mm}$ 以下の小口径管では管の肉厚が薄く，管がコイル状に巻 かれている場合があるので,この場合にはバット融着が 難しく主にソケット融着が使用される。また, 近年継手 の内面に埋め込まれたワイヤーに電気を流し，それによっ

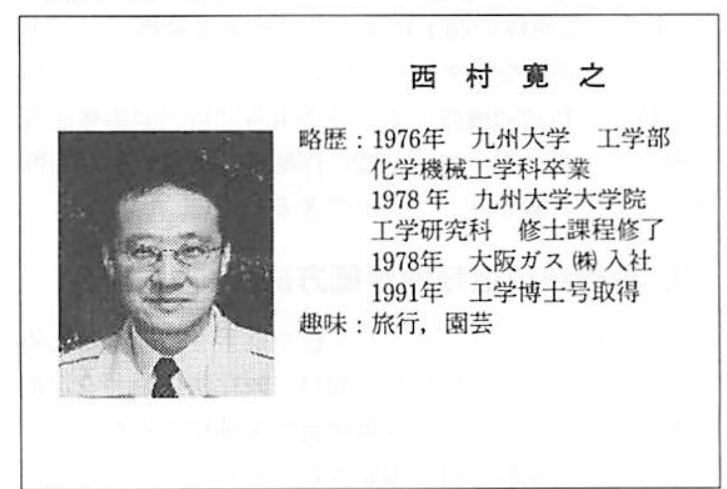



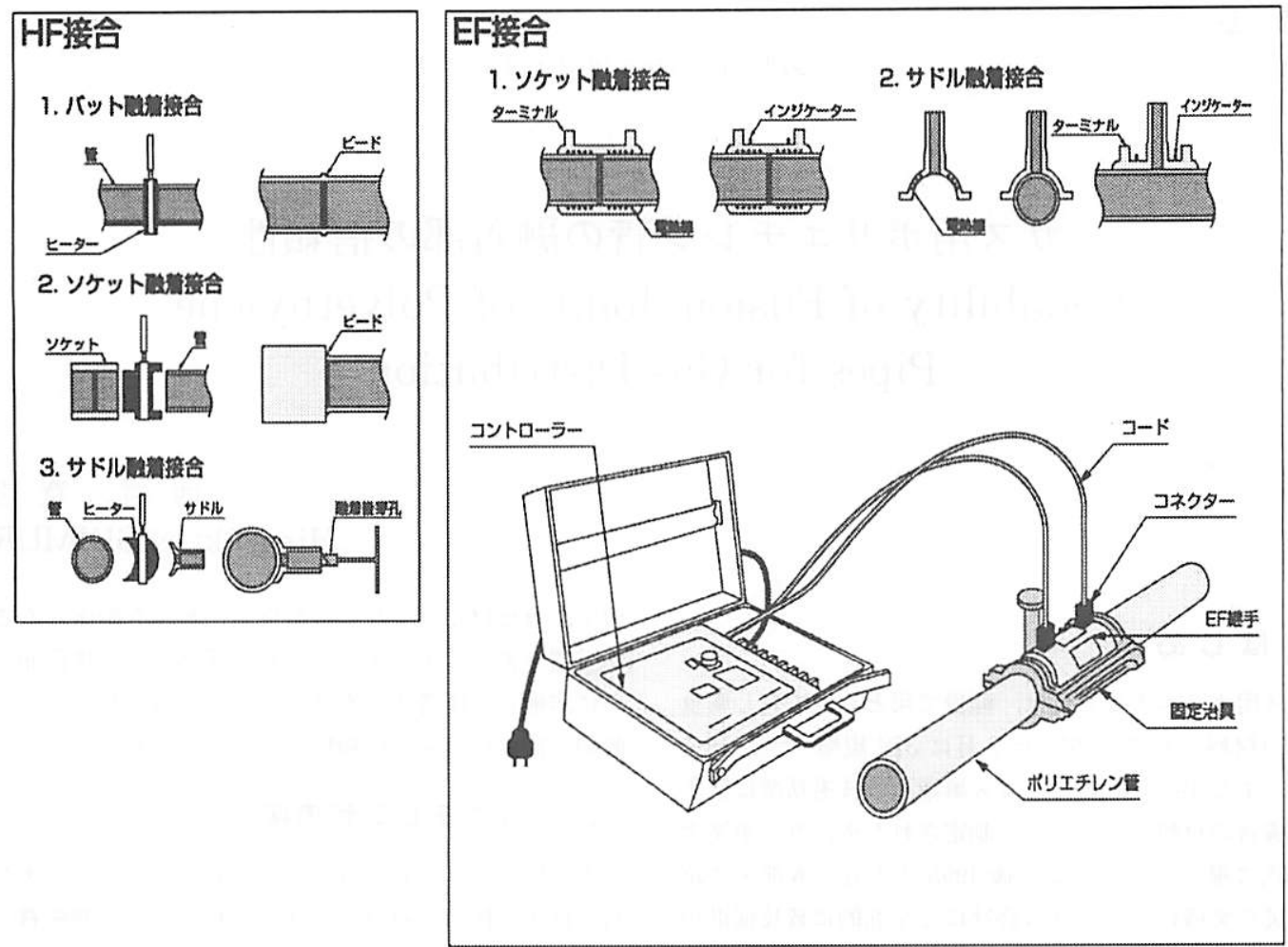

図 $2 \mathrm{HF}$ 継手および $\mathrm{EF}$ 継手の接合毎の融着方法

て樹脂を溶融させて接合する $\mathrm{EF}$ 継手が導入されている。 ポリエチレン管の導入当初は熱融着法が実用化されたが, 管の接合は多くの場合工事現場で行われるため, 熟練性 を要し, 施工品質に個人差が生じたり, 接合工具が多い などの問題があるので, 現場作業性の良い $\mathrm{EF}$ 継手が開 発された。現在, 口径 $100 \mathrm{~mm}$ 以下の継手には $\mathrm{EF}$ 継手 が主に使用されている。

図 2 に HF 継手および $\mathrm{EF}$ 継手の接合毎の融着方法を 一覧にまとめた ${ }^{5)}$ 。 $\mathrm{EF}$ 継手の融着手順は，まず，管の 表面をカンナ掛け後, 管外面之継手内面をアルコール拭 きにて清掃して，固定治具にて管と継手をセットする。 $\mathrm{EF}$ 継手の電熱線の端子にコネクターを接続後, コント ローラーの通電をスタートさせる。コントローラーには, 通電時間自動識別機能あるいは通電時間自己制御機能等 が備えられているので，一般の作業者は通電ボタンを押 すだけで，融着を行うことができる。

\section{3. 融着部の信頼性評価方法}

JIS 規格には，ポリエチレン管や継手を製造するため のコンパウンド (原料樹脂に顔料, 酸化防止剤, 安定剤 等を含有させたもの）の融着適合性を確認するために， 以下の 5 つの試験項目が規定されている11 4)。
・ 引張降伏応力試験

・シャルピー衝揧試験

・内圧クリープ試験

・全周ノッチ式引張クリープ試験

・全周ノッチ式引張疲労試験

これらは保安上の镜点から, 複数の銘柄の樹脂からな る管や継手を使用する場合に，お互いの融着適合性や融 着条件を確認するために定められている。

また, 融着部の信頼性を調べるためには, (1) ビード や継手の幾何形状变化部の応力集中および塑性拘束され た継手近傍の管の強度，(2) 融着界面およびその近傍の 強度特性などを総括的に検討する必要がある。

(1)の観点から, 融着部の性能を調べるためには, 各 種接合方式について応力解析などにより内圧や曲げなど が負荷される場合に発生する応力集中箇所について, 融 着品を疲労試験などの促進武験にて実際に破壊させて接 合形態と破壊強度の関係を検討する必要がある。高温下 での熱間内圧クリープ試験によると, き裂の生成, 成長 は融着部形状によってかなり異なり，き裂は融着界面に 沿ってではなく管または継手の肉厚方向に進むことが多 い。したがって融着部以外に継手の幾何形状が急に変化 する部分も十分に検討しなければならない。 
(2)に関しては, 温度, 時間, 圧力等の融着条件の最 適化が重要であるだけでなく，管の接合は多くの場合工 事現場で行われるため, 管のカンナ掛け, アルコール拭 き等の準備作業も施工品質を向上させるためには重要な 因子となる。

\section{1 接合部寸法}

JIS K6775-1〜 3 に HF 継手や EF 継手等の接合部寸

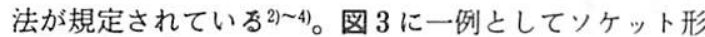
接合の $\mathrm{EF}$ 継手の融着状態における各部寸法の関係を示 す。継手の形状は今後の配管設計技術の進歩によって種々 の形状の継手が追加されることが予想されるので, 従来 の $\mathrm{HF}$ 継手の差込接合（ソケット）継手の接合部寸法と 同椂に，融着接合の基本になる寸法のみが規定されてい る。コールドソーン長さ $1_{1}$ は融着時に溶融樹脂が外部 へ流出し, 電熱線の短絡, 融着圧力の低下を防止するた めに必要な寸法で, ISO 規格や英国ガス仕様にしたがっ て $5 \mathrm{~mm}$ 以上とされている。また, 電熱線部長さ $1_{2}$ は,

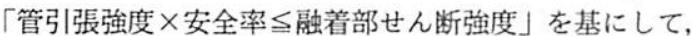
実測值から決められている。継手肉厚 $\mathrm{t}_{1}$ は管と同じ SD $\mathrm{R}^{* 1} 11$ を確保するように設定されており，最小值規定 であるが，内圧等の影響を受けるのは継手の中央部であ るので, ISO 規格に準拠して，継手端部から $2 / 3 \mathrm{~L}$ ま でを除く範囲で規定されている。電熱線部の内径 $\mathrm{d}_{1}$ に 関しては,

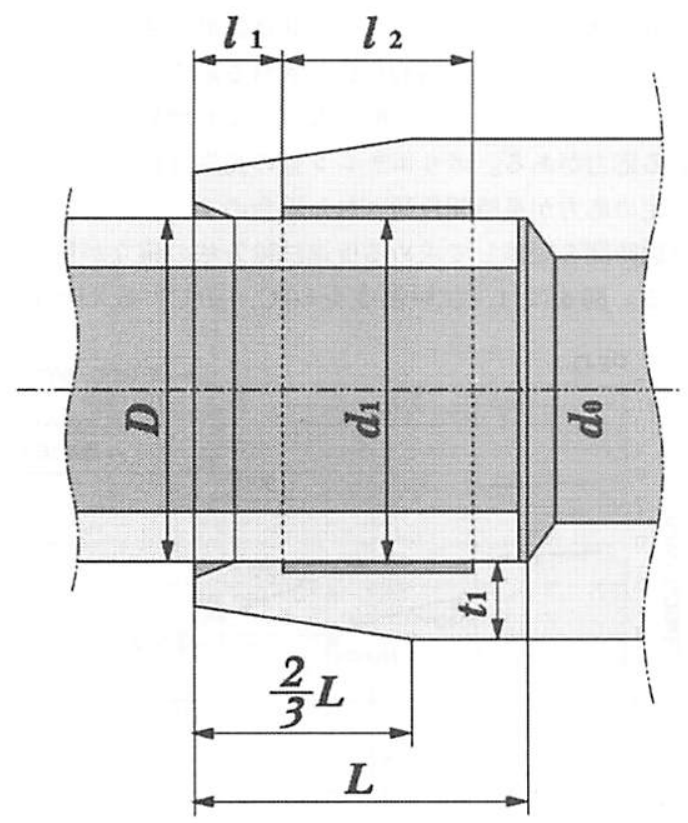

図 3 ソケット形接合の $\mathrm{EF}$ 継手の融着状態における 各部寸法

$$
\begin{aligned}
& \mathrm{d}_{1} \min =\mathrm{D} \max \times 1.002 \\
& \mathrm{~d}_{1} \max =\mathrm{d}_{1} \min +2 \alpha(\alpha: \text { 許容差 })
\end{aligned}
$$

と規定されている。継手受口長さ L は実際的な加熱ゾー ンとコールドソーンから算出されて, 参考値として規定 されている。

$\mathrm{SDR}^{* 1}$ : Standard Dimension Ratio の略で, 管の外径 之肉厚との比

\section{2 短期性能評価方法}

ポリエチレン管の熱融着部の短期性能を評価する方法 としては, 多くの方法 ${ }^{6}$ がこれまでに提案されているが, 引張試験が最む一般的である。一方, 融着条件の適正範 囲を求めたり，管母材と融着部の強度を相対的に比較す るためには, 引張試験のような静的な試験よりも, 衝撃 試験のような動的な試験の方が融着部の性能をより敏感 に評価できることが知られている。ここではバット融着 部を一例に挙げて, 引張試験, 高速引張試験およびシャ ルピー衝撃試験による熱融着部の短期性能評価方法につ いて述べる。

表 1 に実験に用いた 5 種類のガス用ポリエチレン管の 基本物性を示す。 3 種類のポリエチレン管 ( $\mathrm{PE}-\mathrm{D}, \mathrm{PE}$ -E, PE-F) は, JIS K 6774 に規定された口径 $50 \mathrm{~mm}$ または $75 \mathrm{~m}$ の管であり，他の 2 種類のポリエチレン管 (PE-A, PE-H) はASTM D 2513 に規定されている 呼び径 3 インチの管である。

表 1 ポリエチレン管の基本物性

\begin{tabular}{c|c|c|c|c}
\hline 記号 & $\begin{array}{c}\text { 密 度 } \\
\left(\mathrm{g} / \mathrm{cm}^{3}\right)\end{array}$ & $\begin{array}{c}\text { メルトフローレート } \\
\left(\begin{array}{c}2.16 \mathrm{~kg} \\
\mathrm{~g} / 10 \mathrm{~min}\end{array}\right)\end{array}$ & $\begin{array}{c}\text { 重量平均 } \\
\text { 分子量 }\end{array}$ & 分 岥 \\
\hline $\mathrm{PE}-\mathrm{A}$ & 0.936 & 1.20 & $8 \times 10^{4}$ & エテル基 \\
\hline $\mathrm{PE}-\mathrm{D}$ & 0.935 & 0.21 & $12 \times 10^{4}$ & ブチル基 \\
\hline $\mathrm{PE}-\mathrm{E}$ & 0.935 & 0.21 & $14 \times 10^{4}$ & イソブチル基 \\
\hline $\mathrm{PE}-\mathrm{F}$ & 0.935 & 0.20 & $15 \times 10^{4}$ & エテル基 \\
\hline $\mathrm{PE}-\mathrm{H}$ & 0.957 & 0.001 & $\left(36 \times 10^{4}\right)$ & ブチル基 \\
\hline
\end{tabular}

表 2 に引張試験によって得られたバット融着部と管母 材の降伏応力と破断までの伸びを示す。陚験片の厚さは $2 \mathrm{~mm}$, 平行部長さは $10 \mathrm{~mm}$ で, 口径 $75 \mathrm{~mm}$ の管および 熱着部が試験片の中央にくるように切り出された。引張 速度は $200 \mathrm{~mm} / \mathrm{min}$ であった。引張試験の結果では, 管母材とバット融着部の応力ー伸び曲線は同じで, 降伏 応力および破断までの伸びはほとんど一致する。降伏応 力值は管の肉厚設計の基本となるため, 引張降伏応力試 験が JIS 規格に規定されている。また夷際の配管を考 虑して, 継手融着部を含んだ原管引張試験も継手の JIS 
表 2 引張試験の結果

引張速度 : $200 \mathrm{~mm} / \mathrm{min}$ 口 径: $75 \mathrm{~mm}$

$\mathrm{PE}-\mathrm{D}$ 陚験片厚さ: $2 \mathrm{~mm}$

\begin{tabular}{c|c|c|c|c}
\hline \multirow{2}{*}{ 項目 } & \multicolumn{2}{|c|}{ 降伏応力 } & \multicolumn{2}{c}{ 破断までの伸び } \\
\cline { 2 - 5 } 部位 & $\begin{array}{c}\text { 平均值 } \\
\overline{\mathrm{x}}(\mathrm{MPa})\end{array}$ & $\begin{array}{c}\text { 標準偏差 } \\
\sigma(\mathrm{MPa})\end{array}$ & $\begin{array}{c}\text { 平均値 } \\
\overline{\mathbf{x}}(\%)\end{array}$ & $\begin{array}{c}\text { 標準偏差 } \\
\sigma(\%)\end{array}$ \\
\hline 管母材 & 23.0 & 0.15 & 723 & 19.7 \\
\hline バット融着部 & 23.1 & 0.74 & 728 & 37.0 \\
\hline
\end{tabular}

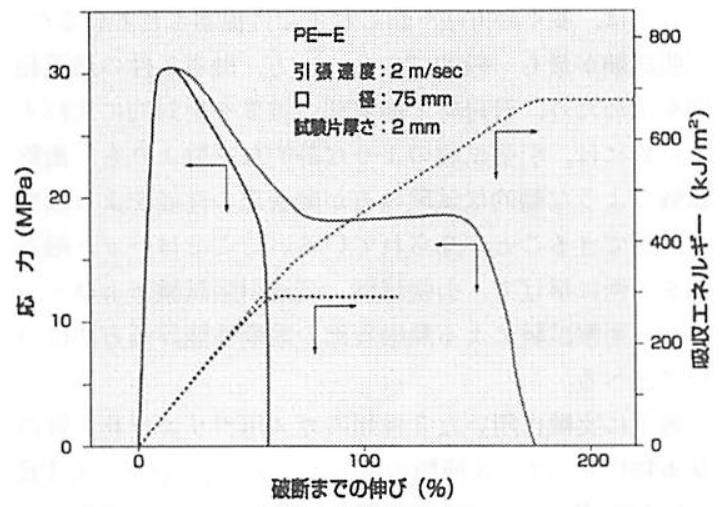

図 4 高速引張試験によるバット融着部と管母材の 応力ー伸び曲線

規格に規定されている。

高速引張試験によって得られたバット融着部と管母材 の応力ー伸び曲線を図 4 に示す。試験片の厚さは $2 \mathrm{~mm}$, 平行部長さは $10 \mathrm{~mm}$ で，口径 $75 \mathrm{~mm}$ の管および熱着部 が中央にくるように切り出された。引張速度は $2 \mathrm{~m} / \mathrm{sec}$ であった。高速引張試験の結果ではバット融着部の衝轱 抗張力は管母材とほとんど等しいが, 破断までの伸びに 関しては，バット融着部は管母材に比べて小さい。これ は融着界面では樹脂の溶融による流動配向やその後の冷 却による再結晶化が起こっているため, 引張速度が速く なると破断に至るまでの変形が起こりにくいことに起因 するものと思われる。図 5 にはバット融着部と管母材の シャルピー衝撃值を示す。試験片の厚さは $4 \mathrm{~mm}$ で，口 径 $75 \mathrm{~mm}$ または 3 インチの管および熱着部が武験片の 中央にくるように切り出され, 深さ $2 \mathrm{~mm}$ の V ノッチ が中央に入れられた。得られた結果は高速引張武験の結 果と同様の傾向を示す。つまり，融着強度は幾分管母材 の強度よりも低下する。ポリエチレン管銘柄間での管母 材のシャルピー衝撃值の相違については, 高分子量夕イ プの $\mathrm{PE}-\mathrm{H}$ が一番高く, $\mathrm{PE}-\mathrm{A}$ が一番低い。一方，パッ 卜融着部の強度低下の程度は，ガス用ポリエチレン管の 銘柄によってかなり異なり，メルトフローレートが小さ

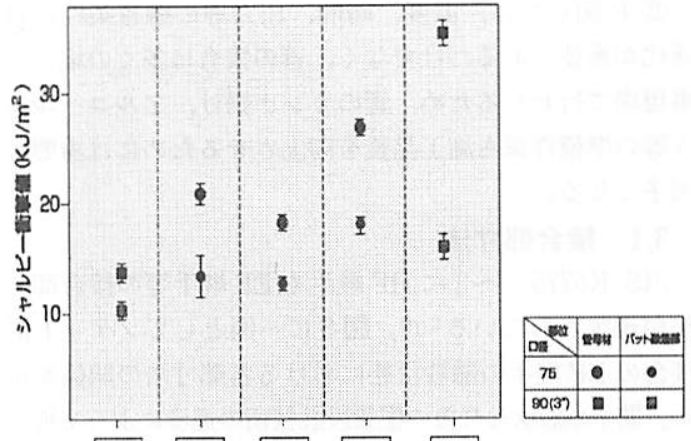

PE-A PE-D PEE PEF PE-H

図 5 シャルピー衛撃試験の結果

く, 溶融樹脂の粘度が高く, 溶融樹脂が界面で十分に流 動しにくい PE-H は, 管母材のシャルピー衝整值に比 べて大きな強度の低下がみられるが, メルトフローレー トが高く, 溶融樹脂の流動性が良い $\mathrm{PE}-\mathrm{A}$ では管母材 に比べて融着強度の低下は少なかった。PE-D, PE-E, $\mathrm{PE}-\mathrm{F}$ は中間的な低下を示すことがわかった。

高速引張試験では, 変位と荷重の関係を求めることが できるが, 試験機が高価なために試験方法としては規格 化されていない。シャルピー衝撃試験が JIS 規格に規 定されている2 吕。

\section{3 長期性能評価方法}

ポリエチレン管は一旦地中に埋設されると補修や取替 えが非常に困難であるので, ポリエチレン管の寿命とし て欧米諸国では数十年から百年間は最低必要と考えられ ている。ガス管に長期的に負荷される応力としては, 内 圧による円周応力と曲げ配管などにより地盤から負荷さ れる応力がある。ポリエチレン管の長期性能評価には, 一定の応力が長時間負荷された場合のクリープ強度を, 武験時間を短縮して求める促進試験方法の確立が重要と なる。図 6 には, 試験温度を $60^{\circ} \mathrm{C}, 80^{\circ} \mathrm{C}$ に变えた場合

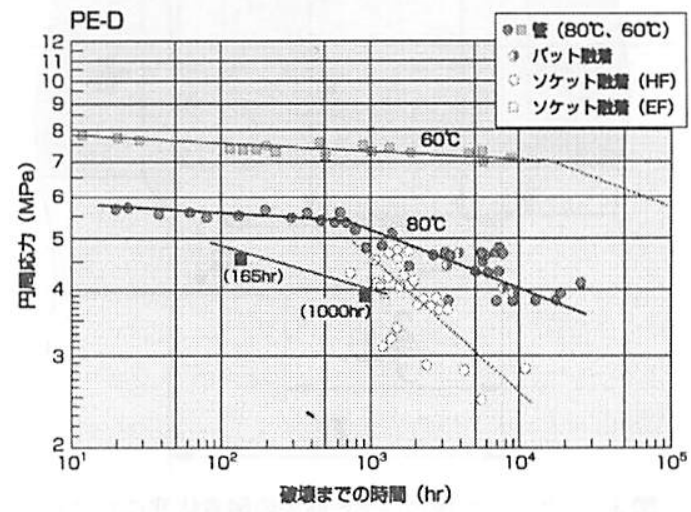

図 6 熱間内圧クリープ試験の結果 


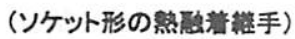

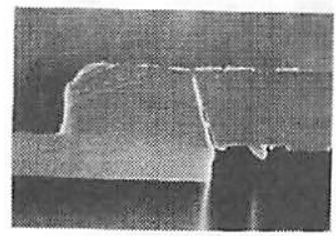

温度: $80^{\circ} \mathrm{C}$

破壤までの時閖: $729 \mathrm{hr}$
円周庞力: $4.2 \mathrm{MPa}$
(ソケット形の電気融諾緥手)

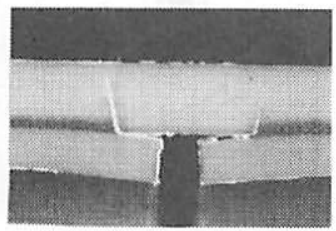

温度: $80^{\circ} \mathrm{C}$

破㙹までの時閒: $4744 \mathrm{hr}$
円周俯力: $3.7 \mathrm{MPa}$

図 7 熱間内圧クリープ武験後のき裂生成と成長箇所の 写真

での管母材の熱間内圧クリープ試験の実測值と，管同士 または管と継手を融着した場合の実測值がプロットされ ている。バット融着部のクリープ強度は管のクリープ強 度とほぼ等しい值を示し, ビード部では応力集中してい るにもかかわらず，管母材で破壊するケースが見られる。 ソケット形継手融着部の場合には, HF 継手融着部之 $\mathrm{EF}$ 継手融着部の両者の強度はほぼ等しいが, 両者とも に継手部の応力集中が大きく影響して, 管母材に比べて 両者のクリープ強度は低下する。

図 7 にはソケット形継手の $\mathrm{HF}$ 継手融着部と $\mathrm{EF}$ 継手 融着部の熱間内圧クリープ試験後のき裂生成と成長䇢所 の写真が示されている。 HF 継手融着部の場合は, き裂 が継手内径側の管と継手との融着コーナー部で生成し,

溶融層を貫通して, 継手母材の中を成長することがわか る。 $\mathrm{EF}$ 継手融着部の場合は, $\mathrm{EF}$ 継手のワイヤーが内 蔵されていないコールドソーンに最む近いワイヤー近傍 から, き裂が生成し, 一部溶融層を通過し, 継手母材の 中を成長することがわかる。

国産樹脂が改良されて, 温度を上げた熱間内圧クリー プ試験でむ, 破壊までの時間が非常に長くかかるように なり, 更に短時間で長期性能を評価する方法が望まれて きた。そこで, 全周ノッチ式引張クリープ試験》と全周 ノッチ式引張疲労試験 ${ }^{81.99}$ が日本で考案された。管の長 手方向から切り出した短冊状の試験片の中央部にカミン リによる全周にノッチを設けて応力集中効果をもたせて いる。

図 8 に全周ノッチ式引張疲労試験の測定結果を示す。 温度は $80^{\circ} \mathrm{C}$, 波形は矩形波で, 周波数は $0.5 \mathrm{~Hz}$ であっ た。3 種類の銘柄の管母材およびバット融着部について, 最大応力と破断までの回数との関係が求められた。3 種 類の銘柄のポリエチレン管ともにバット融着部の強度は 管母材と異なる。その強度の順番は管母材の強度の順番 と一致する。バット融着部強度の低下の程度は樹脂に酔っ てかなり異なり, 高分子量タイプで溶融樹脂の流動性が

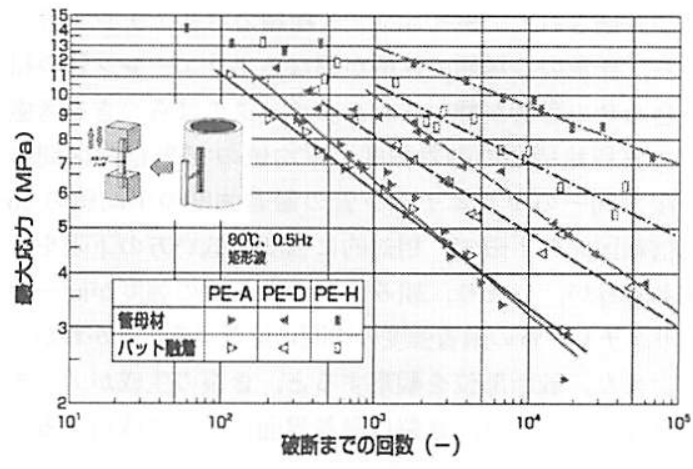

図 8 全周ノッチ式引張疲労試験の結果

覀い $\mathrm{PE}-\mathrm{H}$ では，管母材に比べて大きな低下がみられ た。メルトフローレートの高い $\mathrm{PE}-\mathrm{A}$ では融着部の強 度低下はほとんどみられなかった。 PE-D は両者の中 間的な強度を有することがわかった。

\section{4. 融着適合性の評価}

原料樹脂の異なるあのについては, 一般的にそれぞれ の融着条件が異なっている。また, 同一種類の原料樹脂 から製造されたポリエチレン管であっても，銘柄や品種 が異なる場合には, その基本物性の差により異なる融着 条件が指定される場合がある。したがって, 異種類や異 品種のポリエチレン管を融着する場合には, 同一の融着 条件で問題なく融着が行えること（融着適合性）を確認 する必要がある。

ガス用ポリエチレン管用樹脂の銘柄間の分子構造やメ ルトフローレートは製造方法により多少異なる。銘柄の 異なるポリエチレン管を融着して使用する場合があるの で, 前述の 5 つの試験方法等にて, 融着適合性を評価す ることが必要である。図 9 にシャルピー衝撃試験にてポ リエチレン管の異種銘柄間の組み合わせによる融着適合
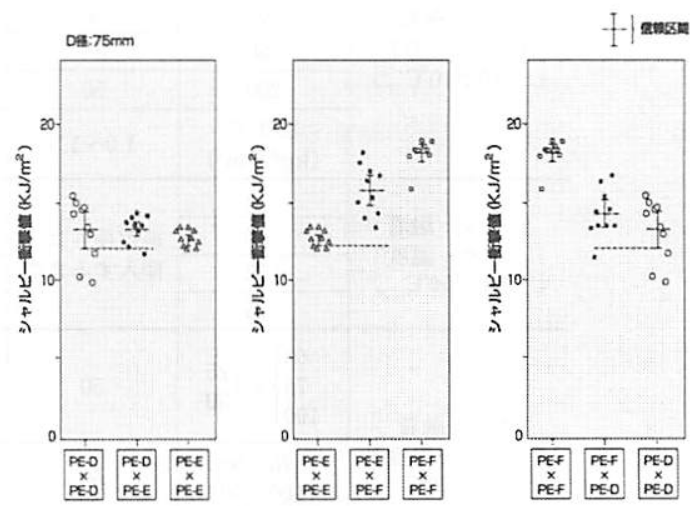

図 9 シャルピー衙撃試験による異種銘柄間の組み合わせ による融着適合性評価 
性が評価された一例を示す。 3 種類のポリエチレン管の うち，任意の 2 種類の銘柄が異なるポリエチレン管の組 み合わせの影響が調べられた。データのばらつきを考虑 して異種銘柄間の融着強度の平均値の $95 \%$ 信頼区間の 下限が同一のポリエチレン管の融着強度の平均値の 95 \%信頼区間の下限で, 相対的に強度の低い方の下限を下 まわらない,つまり, 組み合わせたものの強度が同一の ポリエチレン管の融着強度の中間に位置することがわかっ た。また，破断部位を钼察すると，き裂の生成がノッチ の底部から起こり, き裂は融着界面に沿って成長するこ とがわかった。

\section{5. 融着条件と融着信頼性}

\section{1 熱融着法の融着条件之強度評価}

熱融着法の融着条件因子には，主に加熱温度，加熱時 間, 加圧力の 3 つの因子があるが, 各因子毎の融着強度 に与える影響評価や融着ビード形状・寸法の確認を実施 後, 標準融着条件が設定されている。表 3 にバット融着, ソケット融着, サドル融着の口径毎の標準融着条件を示 す。

図 10 には，国産ポリエチレン管（口径 $75 \mathrm{~mm}$ ）の種々 の融着条件におけるシャルピー衝撃値の相違を示してい る。加熱温度を $150 \sim 270^{\circ} \mathrm{C}$ ，加熱保持時間を $0 \sim 120$ 秒 間，加圧力を $0.25 \sim 2.45 \times 10^{5} \mathrm{~Pa}$ に変えたときのシャル ピー衝撃值を調べると，加熱温度が $170^{\circ} \mathrm{C}$ 以下に低くな る場合や加熱保持時間が 30 秒間以下になるとシャルピー
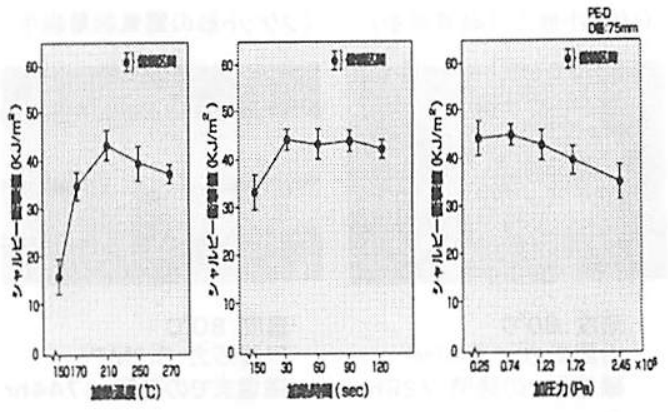

図 10 種々の融着条件におけるシャルピー衝擊值

衝撃值が低くなる。つまり，適正な融着を行うためには 十分な加熱により樹脂を溶融させることが必要である。 また，管同士の端部を圧着させるために一定の圧力を付 加する必要があるが，加圧力が大きすぎると溶融樹脂の せん断速度が大きくなり, 融着部の高次構造が管母材に 比へてて不連続になるため衝撃値が低下する傾向を示す。 加圧力が増加すると溶融樹脂が半径方向にそれだけ多く 流動するため管と融着部の界面が明確に形成され, 衝撃 強度が低下する。熱融着部についていくつかの試験が実 施された後に, 標準融着条件が決められてきた。

\section{2 電気融着法の融着条件之強度評価}

$\mathrm{EF}$ 継手の内側にはワイヤーが内蔵されているので, 融着強度を評価する場合には, 管之継手の融着界面およ び埋め込まれたワイヤー近傍の強度が重要になる。図 11 には，模式的な $\mathrm{EF}$ 継手の融着強度の予測図を示す。一

表 3 融着の種類別口径毎の標軒融着条件

\begin{tabular}{|c|c|c|c|c|c|c|}
\hline \multicolumn{2}{|c|}{ 融着の種類 独好 } & $\begin{array}{c}1 \\
\text { 加圧溶融 } \\
(\text { 秒 })\end{array}$ & $\begin{array}{c}2 \\
\text { 加熱溶融 } \\
\text { (秒) }\end{array}$ & $\begin{array}{c}3 \\
\text { 七-夕ー除去 } \\
(\text { 秒 })\end{array}$ & $\begin{array}{c}4 \\
\text { (秒) }\end{array}$ & $\begin{array}{c}5 \\
\text { (冷 } \\
\text { (秒) }\end{array}$ \\
\hline \multirow{6}{*}{$\begin{array}{c}\text { パット融着 } \\
{\left[\begin{array}{c}\text { ヒーター温度 } \\
210 \pm 10^{\circ} \mathrm{C}\end{array}\right]}\end{array}$} & & 17 & 40 & \multirow{5}{*}{$\begin{array}{c}5 \text { 秒以内 } \\
\left(\begin{array}{c}\text { 七ー夕ー除去から } \\
\text { 圧着開始まで }\end{array}\right)\end{array}$} & 40 以上 & \multirow{5}{*}{180 以上 } \\
\hline & 75 & 17 & 60 & & 60 以上 & \\
\hline & 100 & 30 & 90 & & 90 以上 & \\
\hline & 150 & 35 & 120 & & 120 以上 & \\
\hline & 200 & 50 & 160 & & 160 以上 & \\
\hline & $\begin{array}{c}\text { 加圧力 } \\
\left(\mathrm{kgf} / \mathrm{cm}^{2}\right)\end{array}$ & $1.0 \sim 1.5$ & $0 \sim 0.1$ & - & $1.0 \sim 1.5$ & 0 \\
\hline \multirow{4}{*}{$\begin{array}{c}\text { ソケット融着 } \\
{\left[\begin{array}{c}\text { ヒーター温度 } \\
260 \pm 10^{\circ} \mathrm{C}\end{array}\right]}\end{array}$} & 25 & \multirow{4}{*}{$\begin{array}{l}\text { 規定長さに } \\
\text { 挿入するまで }\end{array}$} & 10 & \multirow{4}{*}{$\begin{array}{c}5 \text { 秒以内 } \\
\left(\begin{array}{c}\text { ヒーター除去から } \\
\text { 压着開始まで }\end{array}\right)\end{array}$} & \multirow{4}{*}{30 以上 } & \multirow{4}{*}{180 以上 } \\
\hline & 30 & & 15 & & & \\
\hline & 50 & & 20 & & & \\
\hline & 75 & & 25 & & & \\
\hline \multirow{3}{*}{$\begin{array}{c}\text { サトル融着 } \\
{\left[\begin{array}{c}\text { ヒーター温度 } \\
260 \pm 10^{\circ} \mathrm{C}\end{array}\right]}\end{array}$} & $\left.\begin{array}{r}60 \\
75 \\
100\end{array}\right\} \times\left\{\begin{array}{l}25 \\
30\end{array}\right.$ & 50 & 0 & \multirow{2}{*}{$\begin{array}{c}6 \text { 秒以内 } \\
\left(\begin{array}{c}\text { ヒーター除去から } \\
\text { 压着開始まで }\end{array}\right)\end{array}$} & 60 以上 & \multirow[t]{2}{*}{180 以上 } \\
\hline & $\begin{array}{r}75 \times 50 \\
100 \times 50\end{array}$ & 60 & 0 & & 90 以上 & \\
\hline & $\begin{array}{c}\text { 加 压力 } \\
\left(\mathrm{kgf} / \mathrm{cm}^{2}\right)\end{array}$ & $0.9 \sim 1.5$ & - & - & $0.9 \sim 1.5$ & 0 \\
\hline
\end{tabular}




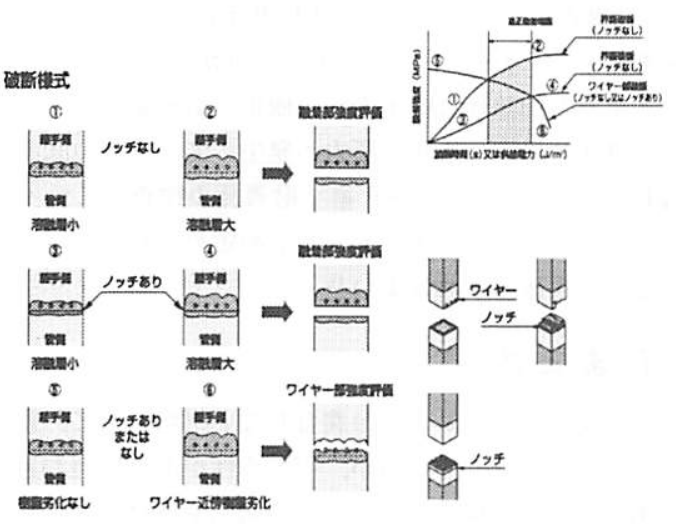

図 11 模式的な $\mathrm{EF}$ 継手の融着強度の予測図

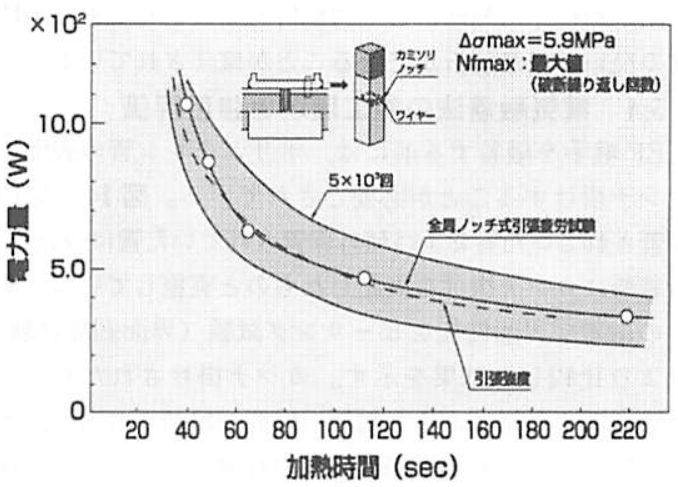

図 13 全周ノッチ式引張疲労武験により求められた電力と 通電時間との関係
般的に電圧を一定にして, 通電時間を増加させていくと, ワイヤーの発熱によりワイヤー近傍の樹脂が徐々に溶融 し, 融着界面の強度む增加していく。しかしながら, 通 電時間が長くなりすぎるとワイヤー近傍の樹脂が高温で 劣化し始めワイヤー近傍の強度が低下する。 $\mathrm{EF}$ 継手融 着部から短冊状試験片を切削加工で切り出し, 引張クリー プ試験等の長期性能評価試験を行うと，まず，融着界面 にノッチのない試験片で, 界面破断強度がワイヤー近傍 での破断強度を上回る遷移点が適正な通電範囲の下限值 で，ノッチのある試験片で界面破断からワイヤー近傍で の破断に移る点が適正な通電範囲の上限値となる。適正 な通電範囲はこの下限値と上限値の間に存在すると考え られる。

$\mathrm{EF}$ 継手の最適な融着条件を設定するためには，供給 する電力と通電時間が重要な設計要因である。図 12 に は試作 $\mathrm{EF}$ 継手から切り出した試験片の全周ノッチ式引 張疲労試験により求めた破断繰り返し数之通電時間の関

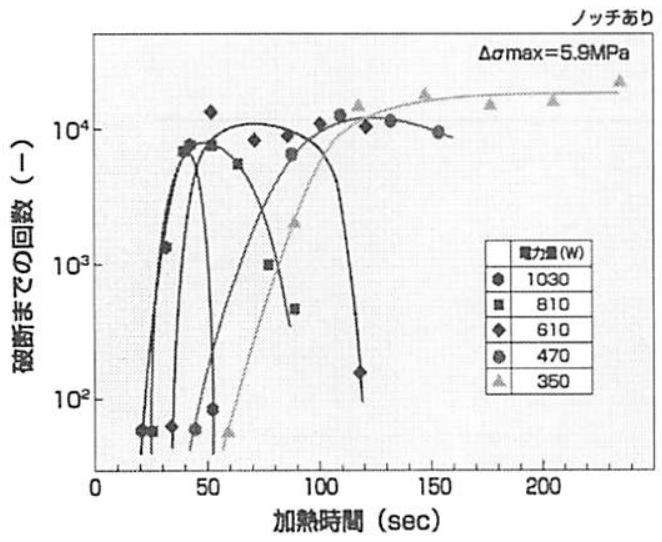

図 12 全周ノッチ式引張疲労武験により求められた破断 繰り返し数之通電時間との関係
係が電力をパラメーターにして示されている。通電時間 が短いと, 樹脂の溶融が不十分で融着強度が上がらない。 一方, 通電時間が長いと, ワイヤーの移動や樹脂の熱劣 化が起こり再び融着強度が低下し, 通電時間が長すぎる と, 融着界面にノッチを入れて応力集中させているにも かかわらず, ワイヤー近傍から破断することか起こる。 また融着部に供給する電力が高くなると，適正な通電時 間の範囲が狭くなり, 電力を下げて緩慢な加熱を行うと, 適正な通電時間の範囲が広くなる。

図 13 には, 全周ノッチ式引張疲労試験により求めた電 力と通電時間の関係が示されている。最大応力 $\Delta \sigma \max =$ $5.9 \mathrm{MPa}$ における破断繰り返し数が最大值 $\mathrm{Nfmax}$ をと る点をプロットすると, 全周ノッチ式引張疲労試験に用 いたものと同じ試験片で，JIS K 6774 に準じて行った 引張試験の強度の最大值を示すラインとよく一致するこ とがわかった。また破断繰り返し数が最大值 $\mathrm{Nfmax}$ の 約 2 分の 1 となる $5 \times 10^{3}$ 回以上を保持する範囲を斜線 で示した。EF 継手の適正な融着条件の範囲は，この斜 線で囲まれた領域とみなすことができる。電力が低すぎ るともはや通電時間を長く設定しても, 融着しない領域 が存在することがわかった。実際に電力を設定するため には，この斜線で囲まれた領域が広いところつまり適正 な通電時間の範囲の広いところが望ましい。

\section{3 電気融着法の融着シミュレーション}

$150 \mathrm{~mm}$ 以上の大口径 $\mathrm{EF}$ 継手の導入検討時，小口径 $\mathrm{EF}$ 継手と同様な試作と実験評価の試行錯詥による設計 評価を行うことは時間的にもコスト的にも負荷が大きく 困難な状況であったので，EF 継手の融着過程を高い精 度でシミュレーションできるプログラム「EPOK」が開 発された。大口径の $\mathrm{EF}$ 継手では, 継手と管の間の初期 ギャップが大きくなりギャップか融着過程に及ぼす影 蠁屯大きくなる。開発されたプログラムは初期ギャップ 
の閉塞過程を伝熱解析と応力解析を連成させており, 精 度の良い非定常解析ができることが確認されている11)。

\section{4 電気融着法の施工環境亡強度評価}

$\mathrm{EF}$ 継手を融着する前には，ポリエチレン管の表面を カンナ掛けすることが必要とされている。図 14 に屋内 保管されていた管および屋外保管されていた管について, 融着時にカンナ掛けを実施したものと実施していないも のの融着部界面性能をピーリング試験（界面剥離試験） により比較した結果を示す。カンナ掛けされたすのは 保管期間の経過によらず初期の性能が維持されるが, 力 ンナ掛けのないあのは保管期間の経過とともに, 屋外保 管品および屋内保管品の延性破面率が低下することがわ かった。施工時にはカンナ掛けが重要であることがわか $3^{12), 13)}$

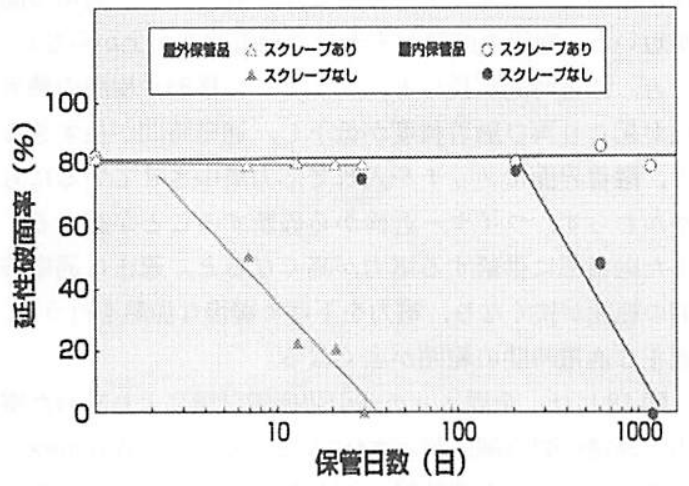

図 14 ピーリング試験の結果

\section{6. 検 査}

$\mathrm{HF}$ 融着継手の場合には，ビード高さと管肉厚（口径） の関係，ビード高さと融着強度の関係が実験的に求めら れているので，ビード高さの適正範囲が規定されている。
$\mathrm{EF}$ 融着継手の場合には， $\mathrm{EF}$ 継手のワイヤー組み込 み部にインジケーターと呼ばれる小孔が空けられており， ワイヤーが加熱され継手内面の樹脂が溶融膨張すると, 管と継手の界面に樹脂の圧力が発生して，小孔の底部が 隆起するあのである。 $\mathrm{EF}$ 継手融着部の検查はこのイン ジケーターの隆起高さがあらかじめ定められた值以上て あることを確認すればよい 12), 13)。

\section{7. まとめ}

ガス用ポリエチレン管は腐食しない材料として, 新設 導管に広く普及しているか，可とう性があり接合が容易 であるので，現場での施工能率の向上や機材の現場搬入 の時間短縮が図れ，工事に伴う道路の使用期間の短縮化 が実現している。また，インサーション工法や非開削工 法等に適用して，土木工事费用や配管工事費用の削減か 図られている。現場での融着作業は施工管理をしっかり することによって, 十分な品質が確保されている。今後 ますますポリエチレン管が定着拡大していくことが期待 される。

\section{参 考 文 献}

1）JIS K 6774 カ゚ス用ポリエチレン管

2） JIS K 6775-1 ガス用ポリエチレン管継手 第 1 部

3) JIS K 6775-2 ガス用ポリエチレン管継手 第 2 部

4） JIS K 6775-3 ガス用ポリエチレン管継手 第 3 部

5）黑岩光之：配管・装置・プラント技術，秋季号，23(2001)

6) D. R. DeCourcy and J. R. Atkinson : J. Mat. Sci., 12, 1535 (1977)

7）西尾宣明：東京ガス技術研究所報告，第 27 号， 73（1983）

8）西村寛之ら：成形加工，1，318 (1989)

9）西村宽之ら：成形加工，1，447 (1989)

10）西村賽之：ガス用ポリエチレン管の破壊機構に関する研究。 博士論文 $(1991)$

11）井上富美夫ら：成形加工，8,80 (1996)

12）日本ガス協会編：ガス用ポリエチレン管技術资料

13）日本ガス協会編：ガス用ポリエチレン管接合作業および教 充・訓練マニュアル 